\title{
CHEMOTHERAPEUTIC TRIALS IN LEPROSY
}

\section{Comparative Trial of Macrocyclon plus Dapsone and Dapsone alone in the treatment of Lepromatous Leprosy}

by M. F. R. WATERS, M.B., M.R.C.P.,

The Research Unit, Sungei Buloh Leprosarium, Malaya, and

The National Institute for Medical Research, London, N.W.7.

\section{Introduction}

Active treatment has been available for leprosy since the introduction of sulphones in 194I and many chemotherapeutic trials have been undertaken. However, with the exception of the series sponsored by the Leonard Wood Memorial (Doull, 1954 and Doull et al., $1957,1958,1961$ ) surprisingly few attempts have been made to apply the standard controlled methods evolved in other branches of medicine, in particular in tuberculosis by the British Medical Research Council (BRADFORD Hill, 1960). Therefore in the first drug trial undertaken by the Research Unit, Sungei Buloh Leprosarium, precise criteria for the selection, treatment and assessment of patients were written into the protocol. It was thereby hoped to elucidate which points were of greater and which were of minor importance in the design of leprosy drug trials. This object was likely to be assisted by choosing a drug which, for ethical reasons required to be tested for its additive effect in association with a known effective drug such as dapsone. Macrocyclon appeared a suitable compound for test.

Macrocyclon is one of the most active and least toxic members of a series of polyoxyethylene ethers developed by CORNFORTH and his colleagues (1951). It is a non-ionic compound of high molecular weight (about 4,000), with surface-acting properties. It has been shown to have considerable chemotherapeutic activity against experimental tuberculosis in the mouse (CORNFORTH et al., 1955) and guinea-pig (REES, 1953) and there is evidence of a synergistic action with dihydrostreptomycin (SolotorovSKY and GrEGORY, 1952). It is concentrated in monocytes, and in cells of the reticulo-endothelial system (LOVELOCK and ReEs, 1955). When monocytes are taken from animals previously treated with macrocyclon, and infected with tubercle bacilli, no intracellular multiplication of bacilli takes place (MACKANESS, 1954). It has been suggested that the surface lipids of tubercle bacilli are modified by the drug, rendering the bacilli more sensitive to digestion within the phagocytic cells (LOVELOCK and REES).

Macrocyclon was used by Boyd et al. (1959) for treating 10 patients with far advanced pulmonary tuberculosis with resistant bacilli, for whom no other remedy was available. No serious toxic 
or side effects were observed, although some rise in the plasma cholesterol was detected, and on very high dosage hypersensitivity rashes and pruritis occurred. No clinical improvement occurred. Perhaps the reason was that in human tuberculosis, unlike in experimental mouse tuberculosis, many bacilli are extracellular. However, both murine and human leprosy resemble murine tuberculosis in this respect, and since ReEs (1957) found that macrocyclon was therapeutically active in experimental murine leprosy, it was considered that a trial in human leprosy was indicated.

\section{Organization and Conduct of the Trial}

\section{Observers}

Responsibility for the day to day organization of the trial and for the clinical care of the patients was vested in the research leprologist. All leprosy clinical assessments were performed by an independent assessor, Dr. K. M. Reddy, who had no knowledge of the treatment received by any patient, and also practically no contact with any patient between assessments. Biopsies were sent, after fixation, by air mail to Dr. D.S. Ridley for histological assessment; no treatment details were given. All smears were taken and read by the research leprologist. This was because special studies were being made of the bacterial morphology, but in practice it was found impossible to remember details of any previous examination.

\section{General Plan of the Trial}

Lepromatous leprosy shows many diverse clinical appearances, and also little is known of the factors which affect prognosis and the rate of response to treatment. In an attempt to overcome these difficulties, and to learn more of the prognostic factors, first, a very careful classification of every patient was made using the method of RIDLEY and JOPLING (1962); and second, the system of 'like pairs', originally advocated by MUIR (1955) was introduced.

A total of fifty patients (twenty-five pairs) was included in the trial. All patients were treated in the research wards, and received a high protein diet. It was planned that the trial should last one year. Because of the slow rate of intake, however, the last three pairs were studied for six months only, whereas the first nine pairs were studied for a total of eighteen months.

\section{Initial Selection of Patients}

On admission, all new patients were examined by the research leprologist. Those satisfying the following criteria were provisionally selected:-

(a) Male Malays, Chinese and Indians (Dravidian), aged 15 years or more, 
(b) having lepromatous leprosy, either pure or with only few atypical features,

(c) not having any other significant organic disease,

(d) having received no previous scientific treatment for leprosy,

(e) whose routine admission chest X-rays showed no evidence of active respiratory or cardiovascular disease.

The one exception to rule $(c)$ was a patient with asymptomatic neurosyphilis who was treated with penicillin and bismuth. Stools from all patients were examined for worm infestation, which was treated whenever found.

In general, no patient who was thought to have received more than 10 injections of dapsone was admitted to the trial. Exceptions were two patients who had received 17 and 14 injections, respectively, who were paired together, a third, 16 injections, and a fourth who had received two courses of injections five and four years prior to admission. As far as could be ascertained, none of the remaining 46 patients had received more than 6 sulphone injections. Dapsone is routinely used in Government Clinics, but owing to local preference for injections, sulphone tablets are little used in Malaya, and it was considered unlikely that any patient had received them. Most patients had however taken traditional Malay, Chinese or Indian remedies.

4. Preliminary Investigations (of provisionally selected patients)

\section{A. General}

(i) Complete clinical and urine examinations.

(ii) Early morning and midday specimens of urine were examined for albumin daily for one week. Patients whose early morning specimens showed faint traces of albumin intermittently were included in the trial, those with midday albuminuria were excluded (McFadZEAN, 1962).

(iii) Weight.

(iv) Examination of sputum, if any.

(v) Haemoglobin; total and differential white blood count.

(vi) Serum protein, total and albumin/globulin ratio, and paper electrophoresis.

B. Leprosy

(i) Clinical examination of the leprosy condition.

(ii) Smears from both ear lobes, and from 4 to 6 selected skin sites from active lesions. These were examined for:

(a) the number of bacilli, the results being recorded using a logarithmic scale of 0 to $6+$ (RIDLEY, 1958).

(b) morphology, recording the proportion of uniformly and of irregularly stained bacilli (WATERS and REES, 1962).

(iii) Two biopsies taken from typical active lesions (RIDLEY). Histopathologically all patients were 'pure lepromatous' (LL) 
—40 patients - or 'near lepromatous' (BL) (RIDLEY and Jopling). Histological diagnosis was determined before the allocation of treatment. The average pretreatment biopsy index for each patient always exceeded 0.5 , save for both members of pair No. 9 .

(iv) Colour photographs.

(v) Lepromin skin test, using $0.1 \mathrm{ml}$. Dharmendra type lepromin, the diameter of the area of induration being recorded in $\mathrm{mm}$. at 48 and 72 hours, and at 1, 2, 3 and 4 weeks.

(vi) Intracutaneous tuberculin test, 1 tuberculin unit (TU) of RT 23, the diameter of the area of induration in $\mathrm{mm}$. being read at 48 and 72 hours. Patients negative $(0-4 \mathrm{~mm}$.) to $1 \mathrm{TU}$ were retested with $20 \mathrm{TU}$.

\section{Initiation of the Trial}

The preliminary investigations, save for the lepromin test, took 2-3 weeks to complete. Patients who failed in any requirement were discarded; moreover any patient, however otherwise suitable, who appeared likely to abscond, was also discarded.

Patients were collected together in pairs of the same race (save for pair No. 21, where a dark skinned Malay patient was paired with an Indian of very similar skin colour), having approximately the same intensity of leprosy infection. BL patients histopathologically, were paired with BL patients. In general any patient still unpaired two months from the day of admission was dropped as it was considered unethical to withhold treatment longer.

\section{Initial Examination by the Independent Assessor}

As suitable pairs were collected the patients were examined individually by the independent assessor who made detailed notes and charts of their lesions on the record sheets. Photographs and smear results, but not biopsy reports, were shown to the assessor.

Next the patients were submitted in their pairs and the assessor was required to reject any which he considered unsatisfactory. He then noted, and carefully recorded differences between the members of each pair, and the relative severity of their leprosy.

\section{Allocation of Treatment}

As each pair was accepted by the assessor the names of the two patients were placed in alphabetical order, the first being designated ' $A$ ', and the second ' $B$ '. The letter ('A' or ' $B$ ') determining which patient was to receive the combined therapy (with dapsone plus macrocyclon) was contained in the next sealed envelope in a numbered series based on random sampling.

\section{Chemotherapy}

Twenty-five patients, one from each pair, received standard dapsone therapy (treatment group D); their partners were treated with dapsone plus macrocyclon (treatment group DM). 
(i) Dapsone (DDS). All patients received intramuscular injections of dapsone in refined coconut oil twice weekly. The initial dose was $200 \mathrm{mg}$; after 6 weeks ( 12 injections) it was raised to $300 \mathrm{mg}$. twice weekly, for the remainder of the 12 months (93 injections).

(ii) Macrocyclon. Given by intravenous injection once a week as a $12.5 \%$ solution in saline, as follows:

$1 \mathrm{st}$ week, $5 \mathrm{ml}$; 2nd week, $10 \mathrm{ml}$; 3 rd week, $15 \mathrm{ml}$; 4th week and subsequently, $50 \mathrm{mg} / \mathrm{Kg}$. body weight (range 14.9-29.4 ml.).

\section{Observations throughout Treatment}

A. General

(i) Haemoglobin and total white blood count-weekly.

(ii) Differential white blood count - monthly.

(iii) Urine-daily (early morning and midday specimens) for albumin.

(iv) Weight-weekly.

(v) Plasma cholesterol.

(vi) Serum proteins; total, A: G ratio and electrophoresis. (v) and (vi) were estimated monthly during the first 6 months, fortnightly during the second 6 months, and for pairs 1-16, a single final reading during the period 15-18 months.

B. Leprosy. Smears from 6-8 skin sites, including both ear lobes, every three months.

\section{Assessment after Six Months' Treatment}

A. General. Each patient had a complete clinical examination, chest X-ray, smears, lepromin and tuberculin tests, colour photographs comparable to the pretreatment photographs and two biopsies from sites adjoining the pretreatment biopsies.

B. Independent Assessor. Before examination of the patients, their antecubital fossae were covered by plaster so that the macrocyclon injection sites could not be recognized. The assessor first examined clinically each patient individually, making detailed notes and charts of lesions. All photographs and smear results were made available, but no biopsy reports.

Af ter each examination, by reference to his pretreatment notes the assessor passed an opinion as to the change if any, in the patient's condition as follows:

No change. Self explanatory.

Improvement. 1. Slight-some diminution in the size of lesions with or without some return to normal pigmentation.

2. Moderate-between slight and marked.

3. Marked-marked diminution in the size of lesions, and possible disappearance of some. 
Deterioration. 1. Slight-some increase in the size of lesions.

2. Moderate- - between slight and marked.

3. Marked-marked extension of lesions, with or without the appearance of new lesions.

Having completed the individual assessments of the 2 members of a pair, the assessor then examined both of them together. First he decided which patient was in the better clinical condition, stating whether the difference was slight, moderate or marked. Then using the detailed notes, charts and photographs, he decided which member of the pair had made the greater progress since the start of treatment, stating whether the difference in progress was slight, moderate or marked.

Finally, the assessor carefully recorded differences between the members of each pair, and in particular, the presence (including type and severity) or absence of any reaction. In all assessments care was taken to distinguish as far as possible between reactions and the underlying lepromatous state.

\section{Assessment after Twelve Months' Treatment}

At the completion of 12 months' treatment, pairs 1-22 were reassessed in the same way as at 6 months. In addition the assessor decided which member of each pair had made the greater progress during the second 6 months of treatment, and whether the difference in progress was slight, moderate or marked.

\section{Assessment after Eighteen Months' Treatment}

All patients remaining in pairs 1-9 were examined at 18 months in the same way as at 6 months. In addition, for the pairs remaining, the assessor decided which member of each pair had made the greater progress during the third 6 months of treatment, and whether the difference in progress was slight, moderate or marked.

\section{Treatment of Reactions}

Although it is generally agreed that 'lepra' reactions have become less severe and prolonged since the introduction of the sulphone drugs, erythema nodosum leprosum (ENL) has become more common and chemotherapy is frequently interrupted on the grounds that reduction or temporary cessation of treatment is beneficial (Cochrane, 1959). As a result in past trials many patients received very different and smaller total dosages of sulphone from those prescribed in the relevant protocols. In this trial it was decided to treat patients in reaction with any or all of the standard drugs including corticosteroids as indicated, but not to alter the dose of the trial drugs (dapsone and macrocyclon) unless all attempts at controlling the reactions had otherwise failed. In fact, during the year of the trial, the dosage of dapsone and macrocyclon was never lowered; 
one patient who was followed for 18 months received a reduced dose of dapsone, and two short rest periods during the third 6 months.

Drugs used in the treatment of reactions included stibophen, calcium laevulinate, chloroquine, antihistamines, teracycline, prednisolone, and corticotrophin.

\section{Treatment received}

The dosage prescribed was strictly adhered to. All patients received 52-53 injections of dapsone (14.4-14.7 g.) during the first 6 months, and those in group DM received 26 injections of macrocyclon. All patients studied in the second 6 months received a further 51-53 injections of dapsone (15.3-15.9 g). Those in group DM received a further 26 injections of macrocyclon. Total dapsone received over the 12 months was $29.7-30.3 \mathrm{~g}$.

The thirteen patients who were followed for a further 6 months were whenever possible allowed to live in the settlement. The dosage of dapsone received during this third period was therefore more variable, totalling $10.0-17.5 \mathrm{~g}$. In addition, the patient who only received $10.0 \mathrm{~g}$. of dapsone was also given $88.5 \mathrm{~g}$. of thiambutosine (DPT, SU 1906).

\section{Results}

\section{Scope of the Analysis}

In the standard type of clinical trial, the results of the different assessments on individuals in one treatment group are compared with those obtained on patients in the other treatment group. By introducing the method of 'like pairs' it is also possible to analyse the differences in the results for the two members of each pair; in addition other results, e.g., relative clinical progress, which depend upon the direct comparison of the two members of each pair, may also be obtained.

Although twenty-five pairs were admitted, during the course of the trial a number of patients were dropped. Thus, not only were the total numbers of patients reduced in the two treatment groups, but also proportionately a greater number of pairs was lost. Because of this reduction in numbers the clinical, histological and bacteriological results are presented as comparisons of the individual assessments on the patients in the two treatment groups; and in addition as a comparison of the relative clinical progress of the members of each pair, which can only be studied on the pairs. Other possible advantages of pairing patients in leprosy drug trials will be the subject of a separate report.

\section{Exclusions from the Analysis}

\section{A. Patients}

Despite the careful selection process, 6 patients absconded for 
longer or shorter periods, and were therefore excluded as follows:

(i) from all analyses: two D and one DM.

(ii) from the 12 months' analysis: one D.

(iii) from the 18 months' analysis: one D and one DM.

One D patient developed pulmonary tuberculosis after 3 months' treatment, and was discarded.

Both patients in pair 9 were excluded because they had very mild leprosy, and their pretreatment biopsy indices were less than 0.5 .

The number of patients selected, and completing assessments, is shown in Table 1.

\section{B. Pairs}

Whenever a patient was lost from a pair, the remaining patient was kept in the trial for the subsequent group analysis. In addition at the end of the trial, but before analysis, the pairs were reconsidered especially with regard to their pretreatment clinical, bacteriological and histological characteristics. It was decided that the original LL and BL classification of 3 patients was incorrect, and that their pairing was unsatisfactory. Such retrospective reclassification is open to considerable criticism. However, this was the first time that the subdivision of lepromatous patients into LL and BL had been attempted in a trial using the method of 'like pairs'. While the ease and value of the subdivision has been proved in practice, it is not surprising that some uncertainty existed over a few patients until sufficient experience had been gained.

Table II shows the number of pairs used in the analysis at each assessment.

\section{Clinical}

The assessment of clinical progress in leprosy is notoriously subjective. Nevertheless, by analogy with the method of radiological assessment of progress used in the Medical Research Council controlled clinical trials in pulmonary tuberculosis (1948 onwards) it was anticipated that the simple classification of progress made by the independent assessor would be sufficient to detect any significant differences in the two treatment groups.

For the statistical analysis, the progress recorded for each 6 months' period was scored as follows:

$\begin{array}{lll}\text { Improvement }- & \text { marked } & 3 \\ \text { moderate } & 2 \\ \text { slight } & 1 \\ \text { No change }- & & 0 \\ \text { Deterioration }- & \text { slight } & -1 \\ & \text { moderate } & -2 \\ & \text { marked } & -3\end{array}$

All patients showed clinical improvement of a lesser or greater degree. The results are given in Table III. 


\section{A. Analysis of Individuals}

Even though there is some suggestion that group DM made rather better clinical progress over the period 0-12 months, none of the differences in the mean clinical progress between the two treatment series attains statistical significance at the $5 \%$ level.

\section{B. Analysis of Pairs}

Comparisons were made in the paired LL patients, both of their relative clinical condition at each successive examination and of their relative clinical progress over the various periods of the trial. (Table IV). No obvious differences were detected.

\section{Histological}

All patients showed histological improvement of a lesser or greater degree. The mean percentage decrease in the Biopsy Index was estimated for the period 0-6 months, 0-12 months, and 0-18 months, for the LL and BL patients. None of the mean differences between the two treatment groups attains statistical significance (Table V).

\section{Bacteriological}

(a) Bacterial index. The majority of pretreatment smears from all sites were $5+(48 \%)$ and $4+(42 \%)$. Only 2 patients had one pretreatment smear site negative (in both cases a compulsory ear site), one patient being BL (No. 21) and the other, although LL, having rapidly progressive disease which had probably recently changed from borderline to lepromatous leprosy, and whose subsequent smears were always positive.

All patients continued to have positive smears except for patient No. 21 -both ears negative at 6 months-and another BL patientone skin site at 18 months.

Every set of 6-8 smears from each patient was averaged. It was found that for 38 patients, 19 in both treatment groups including all BL patients, the end of treatment smears showed an improvement over the pretreatment results. In 3 patients (two DM, and one D) no change occurred in the smear results, and in 3 patients (one DM, and two D) the end of trial smears showed a slight deterioration.

The mean decrease in the average smear results, pretreatment compared with $3,6,9,12$ and 18 months is shown in Table VI. None of the mean differences between the two treatment groups attain statistical significance.

(b) Bacterial morphology. Considerable evidence has recently been produced that leprosy bacilli in biopsy homogenates or smears which stain irregularly by the Ziehl-Neelsen method are almost certainly. dead. The evidence has been summaried by WATERS and REES who have shown that, under the conditions of this trial, a dramatic increase in the percentage of irregularly staining organisms 
occurs in the smears of lepromatous patients following the commencement of chemotherapy. After only 6-9 months' treatment, on average $96 \%$ of bacilli showed irregular staining. Their report was based on the 39 patients in this trial who had had no, or virtually no treatment whatsoever for leprosy.

Table VII shows the mean decreases in percentage of uniformly stained bacilli for the 37 patients in whom the morphology was estimated throughout the trial. The decrease has been studied for the periods $0-3,0-6,0-9$ and $0-12$ months, to determine if combined therapy speeded the change in bacterial morphology, which the smears of all patients showed. None of the mean differences between the two treatment groups attains statistical significance. The periods 9-12, and 12-18 months have also been analysed to confirm that a constant minimum value of $3-4 \%$ had been reached, and to exclude the possibility of the emergence of drug resistance.

\section{Reactions}

(a) Frequency and severity. Reactions are now perhaps the major cause of disability to lepromatous patients on chemotherapy. The results have therefore been analysed to determine if treatment with macrocyclon affected their incidence and severity. Of the reactions experienced by the patients nearly all could be easily classified into the two groups suggested by JoPLING (1959) which we have termed 'Lepra Reaction' and ENL.

Lepra reactions. Occurred chiefly during the first 6 months of treatment and were graded as follows:

\pm doubtful reaction.

+ definite mild reaction, usually responding to standard treatment.

++ moderately severe reaction, usually responding poorly to standard therapy, and often requiring corticosteroids for a short period.

$E N L$. These reactions became more frequent as treatment progressed; 18 of $32 \mathrm{LL}$ patients at 12 months, and 9 of 10 at 18 months had ENL. Of the four patients with ENL at entry to the trial, one had received 16 and another 6 injections of dapsone before admission. Thus only two patients developed ENL while yet untreated.

The severity of ENL has been graded as follows:

+ mild, causing little discomfort, and responding to standard therapy.

++ moderate, usually persistent, and not easily controlled by standard therapy. Where corticosteroids were given, the reaction was easily controlled by $5-15 \mathrm{mg}$. prednisolone daily. 
+++ severe, persistent, causing very considerable discomfort, unaffected by standard therapy; requiring 20-35 mg. prednisolone daily for adequate control.

++++ very severe, usually of the necrotic type, difficult to control even with 35-45 mg. prednisolone daily.

The type and severity of reactions present at each assessment are shown in Table VIII. There is no significant difference between the DM and the D groups at the pretreatment, 6, and 18 months' assessments. At 12 months the greater number of $D$ group LL patients in reaction (Lepra and ENL) compared with group DM is statistically significant at the $5 \%$ level. The corresponding difference for ENL reactions only is not significant, even when the intensity of these reactions is taken into account. It may therefore be that the addition of macrocyclon to standard sulphone therapy reduces slightly the incidence of reactions (Lepra and ENL), but this is uncertain.

(b) Effect

uncertainty whether reactions slow down the rate of improvement of patients on sulphone treatment. A further series of analyses have therefore been made to investigate if any of the assessments have been affected by the presence or absence of a reaction. Under the conditions of this trial there is no evidence of any association between the presence of a reaction and the decrease in the biopsy index, the decrease in the bacterial index, the decrease in the percentage of solid staining bacilli, and the assessment of clinical improvement over the periods $0-6$ and $0-12$ months. Thus the slight difference in clinical progress between the two treatment series over the period 0-12 months cannot be explained solely by the greater frequency of ENL at 12 months in the D group.

\section{Comparison of $\mathrm{LL}$ and $\mathrm{BL}$ patients}

The relative clinical progress of the $38 \mathrm{LL}$ patients compared with the $6 \mathrm{BL}$ patients is shown in Table IX. This shows that the BL patients made greater progress; the difference between the mean clinical progress of the patients with the two types of disease is significant at the $2 \%$ level at $0-6$ months, and at the $1 \%$ level at 0-12 months. The differences in histological and bacteriological progress between the LL and BL patients has been shown in Tables IV and V, respectively. In addition, 19 of the $38 \mathrm{LL}$ patients developed ENL but none of the $6 \mathrm{BL}$ patients did.

\section{Lepromin Tests}

(a) Pretreatment. All early and late reactions were negative (less than $5 \mathrm{~mm}$.) save for $2 \mathrm{LL}$ and 2 BL patients who had 'doubtful' early readings of 5-6 $\mathrm{mm}$. 
(b) Six months. Five LL patients had early readings of 5-7 $\mathrm{mm}$. One BL patient had an early reading of $8 \mathrm{~mm}$. and another (No. 21) who was suffering from a lepra reaction, had positive readings of 11 and $10 \mathrm{~mm}$. at 48 and 72 hours, respectively. All other early readings and all late readings were negative.

(c) Twelve months. All early and late readings were negative save for early readings of 5-6 mm. in $6 \mathrm{LL}$ patients, and $1 \mathrm{BL}$ who alone had doubtful positive $(5-8 \mathrm{~mm}$.) readings at 0,6 and 12 months.

\section{Serum Proteins in relation to Therapy}

The average serum protein figures, total, and percentage albumin and gamma globulin, have been estimated for the two treatment groups at $0,6,12$ and 18 months. The decreases in the percentage of gamma globulin in the two treatment series has been analysed for the periods $0-6,0-12$, and $0-18$ months, and none of the mean differences attains statistical significance.

\section{Evidence of Drug Toxicity}

(a) Dapsone. None of the patients showed any evidence of sensitivity.

(b) Macrocyclon.

(i) Plasma cholesterol. A significantly greater rise was detected in the plasma cholesterol of the DM patients than of the D patients. Within 3-6 months of completing the course of macrocyclon however, the level had returned to normal. The mean increases in plasma cholesterol are shown in Table X.

(ii) Blood pressure. No effect was detected.

(iii) Haemoglobin. The average pretreatment haemoglobin level for all patients was $14.1 \mathrm{~g} . \%$ (range 17.3-10.9). A slight fall in average haemoglobin levels occurred in both treatment groups in LL patients (DM, 0.82 and D, $0.50 \mathrm{~g} . \%$ ) which was considered to be due partly to sulphone therapy and partly as a result of reactions. The lowest recorded figure in a patient with ENL was 9.1 g. \%.

(iv) White blood count. No leucopenia was detected. Leucocytosis often occurred in ENL, and also occasionally in response to intercurrent infections.

(v) Albuminuria. A faint trace of albumin was detected at times in early morning specimens of urine from all patients. There was no evidence to connect it with therapy.

(vi) Weight. Nearly all patients were in a satisfactory state of nutrition on admission. The average weight gained in one year was $4 \frac{1}{4} \mathrm{lb}$. for the DM group, and $2 \frac{1}{4} \mathrm{lb}$. for D group.

(vii) Skin rashes. Three patients in the DM group had brief episodes of irritant skin rashes which cleared without interruption of macrocyclon treatment. 


\section{Discussion}

Under the conditions of the trial here reported there is no evidence that the addition of macrocyclon to parenteral dapsone therapy significantly alters the clinical, histological or bacteriological rates of response to treatment. Even the finding that the overall incidence of 'lepra' and erythema nodosum leprosum (ENL) reactions was significantly lower in the combined therapy (DM) group must be treated with some reserve. For the mechanisms of the two types of reaction are almost certainly very different in nature, and the analyses of their incidence separately (as opposed to the combined incidence) did not yield statistically significant results. It is proposed to discuss in a further report the value of testing new antileprosy drugs in combination with dapsone, together with possible refinements of the methods used in this trial.

Leprosy in Malaya, especially in the Chinese and Malay races is very unstable. There is a marked tendency, in the absence of chemotherapy, for patients to deteriorate towards the lepromatous end of the spectrum or 'continuum' of WADE (1961). The majority of undoubted lepromatous patients at Sungei Buloh Leprosarium are found on careful clinical examination to have one or more plaques or annular lesions possessing the characteristics of borderline leprosy, and nerve enlargement is often not completely bilaterally symmetrical. Yet in their rate of progress and ultimate prognosis, and also in their liability to develop ENL they resemble patients with clinically 'pure' lepromatous leprosy. It was therefore essential in this trial to make a careful classification of the patients studied, by using all available prognostic factors, clinical, histological, bacteriological and immunological. The system of classification for research purposes suggested by RIDLEY and JOPLING has been adopted, and has worked well in practice. It was decided to admit near-lepromatous $(\mathrm{BL})$ as well as pure lepromatous (LL) patients to the trial, and once experience had been gained, there was remarkably little disagreement over the correct classification of individuals.

The relative severity of the disease in untreated patients admitted to Sungei Buloh is probably related to the frequency with which lepromatous leprosy evolves from borderline leprosy in Malaya. The majority of lepromatous patients are already at the moderately severe $\left(L_{2}\right)$ stage, even when the history of symmetrical spread is of only a few months duration. Early pure lepromatous patients $\left(L_{1}\right)$ are relatively uncommon, and were in effect excluded from this trial as their biopsy indices are usually less than 0.5 . Thus all LL patients studied were at the $\mathrm{L}_{2}$ or $\mathrm{L}_{3}$ stages of the disease.

With the facilities available at Sungei Buloh leprosarium it was considered safe to give a high initial dose of dapsone $(200 \mathrm{mg}$. twice weekly), and to increase to full dosage after only six weeks. This high 
initial dose schedule probably accelerated and made more obvious the degenerative changes in the morphology of Mycohacterium leprae in our patients, in this way aiding the quantitative morphological assessments. No patient appears to have suffered any ill effects from the prescribed dose schedule. No case of sulphone sensitivity occurred, and the overall incidence of ENL $(50 \%$ of LL patients) is similar to other treatment series (Doull et al., 1957, 1958, 1961).

Similarly, the decision to keep patients with ENL on full antileprosy treatment (giving corticosteroids as and when required), while not generally advocated, has enabled the relationship between reactions and the response to treatment to be specially studied. As a result it would appear that the poorer response of ENL patients to chemotherapy which hasbeen widely reported (Doull et al., 1957, DAvison and KoolJ, 1957) is not due to a direct action of the ENL but to the reduction or cessation of active treatment compelled by the reaction.

Because of the finding in this trial that after 9 months' treatment $96 \%$ of bacilli in skin smears are almost certainly dead, it has been suggested that drugs which assist in the breakdown of effete mycobacteria might be of special value in lepromatous leprosy. Because macrocyclon has surface-acting properties, alters the sensitivity of red blood corpuscles to thermal shock, is thought on theoretical grounds to act on the mycobacterial cell wall (LOVELOCK and REEs), and is retained in monocytes for several weeks, it was decided relatively late in the trial to study a number of patients for a third 6 months' period. This was written into the protocol, and pairs 1-9 were assessed at 18 months after commencing treatment. There was, however, no evidence either of a late effect of macrocyclon, or that macrocyclon speeded the destruction and removal by the body of fragmented and granular bacilli.

\section{Summary}

1. A controlled clinical trial is reported of combined dapsone and macrocyclon therapy compared with dapsone alone in the treatment of pure lepromatous and near lepromatous leprosy.

2. Twenty-five untreated, matched pairs were admitted to the trial, and the final analysis was made on 16 pairs and 44 patients, 21 of whom received dapsone, and 23 combined therapy.

3. The treatment regime was unusual in that, $(a)$ a high initial dose of dapsone $(200 \mathrm{mg}$. twice weekly by injection) was used; (b) the full dose schedule was maintained despite the occurrence of erythema nodosum leprosum.

4. Under the carefully controlled conditions of the trial it was concluded that

(a) All 44 patients showed improvement, 
(b) the addition of macrocyclon to dapsone treatment failed to increase the rate of clinical, histological or bacteriological movement,

(c) the addition of macrocyclon may have reduced the incidence of reactions,

(d) all patients showed a dramatic fall in the percentage of solid staining organisms in skin smears, and after 9 months on average $96 \%$ of leprosy bacilli examined were irregularly stained.

\section{Acknowledgements}

The Research Unit, Sungei Buloh Leprosarium, is under the auspices of the Malayan Ministry of Health, and is directed by a member of the scientific staff of the British Medical Research Council, seconded from the National Institute for Medical Research, London. The present trial was designed by Dr. J. A. McFadzean with the assistance of a sub-committee (Drs. P. D'Arcy Hart, R. J. W. Rees, D. S. Ridley and Ian Sutherland), and co-ordinated in London by the National Institute for Medical Research (Dr. R. J. W. Rees).

Grateful acknowledgements are made to Dato' Dr. Mohd. Din bin Ahmad, Director of Medical Services, Malaya, and Drs. K. M. Reddy and M. K. Bhojwani, successive Medical Superintendents of Sungei Buloh Leprosarium, for their support and encouragement.

I wish specially to thank Dr. K. M. Reddy for acting as Independent Assessor, Dr. D. S. Ridley, Pathologist, Hospital for Tropical Diseases, London, for all histological classifications and assessments, and Dr. Ian Sutherland of the Medical Research Council's Statistical Research Unit for the statistical analyses.

I also wish to thank the Leprosarium staff, and in particular, Mrs. E. Abbey, S.R.N., and her nursing staff; Inche Mohd. Bakri for technical assistance; Dr. M. R. J. Snelling for chest X-ray reports; The Director of the Institute for Medical Research, Kuala Lumpur, and the Division of Biochemistry for supervision of the serum protein and plasma cholesterol determinations; Major R. Thomas, R.E., F.R.P.S., for photographic advice; and Imperial Chemical Industries, Ltd., for supplying the macrocylon.

TABLE I

Number of patients selected and completing assessments

\begin{tabular}{c|c|c|c|c|c|c|c|c|c|c|c|c}
\hline $\begin{array}{c}\text { Assessment } \\
\begin{array}{c}\text { Type of } \\
\text { Leprosy }\end{array}\end{array}$ & \multicolumn{2}{|c|}{ Pretreatment } & \multicolumn{3}{|c|}{6 months } & \multicolumn{3}{|c|}{12 months } & \multicolumn{3}{|c|}{18 months } \\
\hline $\begin{array}{c}\text { Treatment } \\
\begin{array}{c}\text { Group } \\
\text { DM }\end{array}\end{array}$ & BL & Total & LL & BL & Total & $L L$ & BL & Total & $L L$ & $B L$ & Total \\
D & 19 & 6 & 25 & 20 & 3 & 23 & 17 & 3 & 20 & 5 & 2 & 7 \\
\hline
\end{tabular}




\section{TABLE II}

Number of pairs at each assessment

\begin{tabular}{|c|c|c|c|c|c|c|c|c|c|}
\hline \multirow{2}{*}{$\frac{\text { Assessment }}{\text { Type of Leprosy }}$} & \multicolumn{3}{|c|}{6 months } & \multicolumn{3}{|c|}{12 months } & \multicolumn{3}{|c|}{18 months } \\
\hline & $L L$ & $B L$ & Total & $L L$ & $B L$ & Total & $L L$ & $B L$ & Total \\
\hline No. of pairs & 16 & 1 & 17 & 13 & 1 & 14 & 4 & - & 4 \\
\hline
\end{tabular}

\section{TABLE III}

Scores of Clinical Progress

\begin{tabular}{|c|c|c|c|c|c|c|}
\hline $\begin{array}{l}\text { Type of } \\
\text { discase }\end{array}$ & $\begin{array}{c}\text { Period } \\
\text { (months) }\end{array}$ & $\begin{array}{l}\text { Treatment } \\
\text { series }\end{array}$ & $\begin{array}{l}\text { No. of } \\
\text { Patients }\end{array}$ & $\begin{array}{l}\text { Mean } \\
\text { Score }\end{array}$ & $S D$ & $S E m$ \\
\hline \multirow{4}{*}{ LL } & $0-6$ & $\begin{array}{r}\mathrm{DM} \\
\mathrm{D}\end{array}$ & $\begin{array}{l}20 \\
18\end{array}$ & $\begin{array}{l}1.30 \\
1.22\end{array}$ & $\begin{array}{l}0.47 \\
0.55\end{array}$ & $\begin{array}{l}0.11 \\
0.13\end{array}$ \\
\hline & $6-12$ & $\begin{array}{r}\mathrm{DM} \\
\mathrm{D}\end{array}$ & $\begin{array}{l}17 \\
15\end{array}$ & $\begin{array}{l}1.24 \\
0.93\end{array}$ & $\begin{array}{l}0.44 \\
0.26\end{array}$ & $\begin{array}{l}0.11 \\
0.07\end{array}$ \\
\hline & $0-12^{*}$ & $\begin{array}{r}\mathrm{DM} \\
\mathrm{D}\end{array}$ & $\begin{array}{l}17 \\
15\end{array}$ & $\begin{array}{l}2.59 \\
2.20\end{array}$ & $\begin{array}{l}0.71 \\
0.68\end{array}$ & $\begin{array}{l}0.17 \\
0.17\end{array}$ \\
\hline & $12-18$ & $\begin{array}{r}\mathrm{DM} \\
\mathrm{D}\end{array}$ & $\begin{array}{l}5 \\
5\end{array}$ & $\begin{array}{l}1.00 \\
0.80\end{array}$ & $\begin{array}{l}0.00 \\
0.45\end{array}$ & $\begin{array}{l}0.00 \\
0.20\end{array}$ \\
\hline \multirow{4}{*}{ BL } & $0-6$ & $\begin{array}{r}\mathrm{DM} \\
\mathrm{D}\end{array}$ & $\begin{array}{l}3 \\
3\end{array}$ & $\begin{array}{l}1.67 \\
2.00\end{array}$ & $\begin{array}{l}0.58 \\
0.00\end{array}$ & $\begin{array}{l}0.33 \\
0.00\end{array}$ \\
\hline & $6-12$ & $\begin{array}{r}\mathrm{DM} \\
\mathrm{D}\end{array}$ & $\begin{array}{l}3 \\
2\end{array}$ & $\begin{array}{l}1.67 \\
1.50\end{array}$ & $\begin{array}{l}0.58 \\
0.71\end{array}$ & $\begin{array}{l}0.33 \\
0.50\end{array}$ \\
\hline & $0-12^{*}$ & $\begin{array}{r}\mathrm{DM} \\
\mathrm{D}\end{array}$ & $\begin{array}{l}3 \\
2\end{array}$ & $\begin{array}{l}3.33 \\
3.50\end{array}$ & $\begin{array}{l}1.15 \\
0.71\end{array}$ & $\begin{array}{l}0.67 \\
0.50\end{array}$ \\
\hline & $12-18$ & $\begin{array}{r}\mathrm{DM} \\
\mathrm{D}\end{array}$ & $\begin{array}{l}2 \\
1\end{array}$ & $\begin{array}{l}1.50 \\
1.00\end{array}$ & $\begin{array}{l}0.71 \\
0.00\end{array}$ & $\begin{array}{l}0.50 \\
0.00\end{array}$ \\
\hline
\end{tabular}

* sum of readings for $0-6$ and $6-12$ months

TABLE IV

Comparison in paired LL patients of clinical progress in various periods

\begin{tabular}{|c|c|c|c|c|c|c|c|c|}
\hline \multirow[b]{2}{*}{$\underset{\text { (months) }}{\text { Period }}$} & \multirow[b]{2}{*}{$\begin{array}{c}\text { No. } \\
\text { of } \\
\text { pairs }\end{array}$} & \multicolumn{3}{|c|}{$\begin{array}{l}\text { Patient on } D M \text { better } \\
\text { than patient on } D\end{array}$} & \multirow{2}{*}{$\begin{array}{c}\text { No } \\
\text { Difference } \\
\\
0\end{array}$} & \multicolumn{3}{|c|}{$\begin{array}{c}\text { Patient on D better than } \\
\text { Patient on DM }\end{array}$} \\
\hline & & $\underset{3}{\text { marked }}$ & $\underset{2}{\text { moderate }}$ & slight & & slight & $\underset{2}{\text { moderate }}$ & $\underset{3}{\operatorname{marked}}$ \\
\hline $0-6$ & 16 & 0 & 1 & 1 & 8 & 6 & 0 & 0 \\
\hline $6-12$ & 13 & 0 & 2 & 5 & 2 & 2 & 2 & 0 \\
\hline $0-12$ & 13 & 0 & 1 & 7 & 3 & 2 & 0 & 0 \\
\hline $12-18$ & 4 & 0 & 1 & 1 & 2 & 0 & 0 & 0 \\
\hline $0-18$ & 4 & 0 & 0 & 1 & 3 & 0 & 0 & 0 \\
\hline
\end{tabular}

There is no obvious difference between the clinical effects of the two treatments in paired patients 
TABLE V

Percentage decrease in Biopsy Index

\begin{tabular}{|c|c|c|c|c|c|c|}
\hline $\begin{array}{l}\text { Type of } \\
\text { disease }\end{array}$ & $\begin{array}{c}\text { Period } \\
\text { (months) }\end{array}$ & $\begin{array}{c}\text { Treatment } \\
\text { series }\end{array}$ & $\begin{array}{l}\text { No. of } \\
\text { Patients }\end{array}$ & $\begin{array}{c}\text { Mean. } \\
\text { Decrease }\end{array}$ & $S D$ & $S E m$ \\
\hline \multirow{3}{*}{ LL } & $0-6$ & $\begin{array}{r}\mathrm{DM} \\
\mathrm{D}\end{array}$ & $\begin{array}{l}20 \\
18\end{array}$ & $\begin{array}{l}30.0 \\
23.4\end{array}$ & $\begin{array}{l}30.23 \\
56.06\end{array}$ & $\begin{array}{r}6.76 \\
13.21\end{array}$ \\
\hline & $0-12$ & $\begin{array}{r}\mathrm{DM} \\
\mathrm{D}\end{array}$ & $\begin{array}{l}17 \\
14\end{array}$ & $\begin{array}{l}51.3 \\
51.2\end{array}$ & $\begin{array}{l}21.06 \\
27.20\end{array}$ & $\begin{array}{l}5.11 \\
7.27\end{array}$ \\
\hline & $0-18$ & $\begin{array}{r}\mathrm{DM} \\
\mathrm{D}\end{array}$ & $\begin{array}{l}5 \\
4\end{array}$ & $\begin{array}{l}55.6 \\
75.6\end{array}$ & $\begin{array}{l}37.70 \\
18.52\end{array}$ & $\begin{array}{r}16.86 \\
9.26\end{array}$ \\
\hline \multirow{3}{*}{ BL } & $0-6$ & $\begin{array}{r}\mathrm{DM} \\
\mathrm{D}\end{array}$ & $\begin{array}{l}3 \\
3\end{array}$ & $\begin{array}{r}6.3 \\
47.6\end{array}$ & $\begin{array}{l}21.96 \\
38.52\end{array}$ & $\begin{array}{l}12.68 \\
22.24\end{array}$ \\
\hline & $0-12$ & $\begin{array}{r}\mathrm{DM} \\
\mathrm{D}\end{array}$ & $\begin{array}{l}3 \\
2\end{array}$ & $\begin{array}{l}82.2 \\
73.8\end{array}$ & $\begin{array}{l}18.15 \\
22.98\end{array}$ & $\begin{array}{l}10.48 \\
16.25\end{array}$ \\
\hline & $0-18$ & $\begin{array}{r}\mathrm{DM} \\
\mathrm{D}\end{array}$ & $\begin{array}{l}2 \\
0\end{array}$ & $\begin{array}{c}87.8 \\
-\end{array}$ & 10.96 & $\begin{array}{l}7.75 \\
-\end{array}$ \\
\hline
\end{tabular}

None of the above mean differences between the two treatment series attains statistical significance

\section{TABLE VI}

Decreases in Bacterial Index

\begin{tabular}{|c|c|c|c|c|c|c|}
\hline $\begin{array}{l}\text { Type of } \\
\text { disease }\end{array}$ & $\begin{array}{c}\text { Period } \\
\text { (months) }\end{array}$ & $\begin{array}{c}\text { Treatment } \\
\text { series }\end{array}$ & $\begin{array}{c}\text { No. of } \\
\text { Patients }\end{array}$ & $\begin{array}{c}\text { Mean } \\
\text { Decrease }\end{array}$ & $S D$ & SEm \\
\hline \multirow{5}{*}{ LL } & $0-3$ & $\begin{array}{r}\mathrm{DM} \\
\mathrm{D}\end{array}$ & $\begin{array}{l}20 \\
18\end{array}$ & $\begin{array}{r}0.04 \\
-0.01\end{array}$ & $\begin{array}{l}0.28 \\
0.40\end{array}$ & $\begin{array}{l}0.06 \\
0.09\end{array}$ \\
\hline & $0-6$ & $\begin{array}{r}\mathrm{DM} \\
\mathrm{D}\end{array}$ & $\begin{array}{l}20 \\
18\end{array}$ & $\begin{array}{l}0.24 \\
0.08\end{array}$ & $\begin{array}{l}0.32 \\
0.34\end{array}$ & $\begin{array}{l}0.07 \\
0.08\end{array}$ \\
\hline & $0-9$ & $\begin{array}{r}\mathrm{DM} \\
\mathrm{D}\end{array}$ & $\begin{array}{l}17 \\
15\end{array}$ & $\begin{array}{l}0.44 \\
0.22\end{array}$ & $\begin{array}{l}0.46 \\
0.50\end{array}$ & $\begin{array}{l}0.11 \\
0.13\end{array}$ \\
\hline & $0-12$ & $\begin{array}{r}\mathrm{DM} \\
\mathrm{D}\end{array}$ & $\begin{array}{l}17 \\
15\end{array}$ & $\begin{array}{l}0.56 \\
0.25\end{array}$ & $\begin{array}{l}0.48 \\
0.46\end{array}$ & $\begin{array}{l}0.12 \\
0.12\end{array}$ \\
\hline & $0-18$ & $\begin{array}{r}\mathrm{DM} \\
\mathrm{D}\end{array}$ & $\begin{array}{l}5 \\
5\end{array}$ & $\begin{array}{l}0.48 \\
0.50\end{array}$ & $\begin{array}{l}0.41 \\
0.34\end{array}$ & $\begin{array}{l}0.18 \\
0.15\end{array}$ \\
\hline \multirow{5}{*}{ BL } & $0-3$ & $\begin{array}{r}\mathrm{DM} \\
\mathrm{D}\end{array}$ & $\begin{array}{l}3 \\
3\end{array}$ & $\begin{array}{l}0.53 \\
0.07\end{array}$ & $\begin{array}{l}0.47 \\
0.59\end{array}$ & $\begin{array}{l}0.27 \\
0.34\end{array}$ \\
\hline & $0-6$ & $\begin{array}{r}\mathrm{DM} \\
\mathrm{D}\end{array}$ & $\begin{array}{l}3 \\
3\end{array}$ & $\begin{array}{l}0.53 \\
0.43\end{array}$ & $\begin{array}{l}0.40 \\
0.75\end{array}$ & $\begin{array}{l}0.23 \\
0.43\end{array}$ \\
\hline & $0-9$ & $\begin{array}{r}\mathrm{DM} \\
\mathrm{D}\end{array}$ & $\begin{array}{l}3 \\
2\end{array}$ & $\begin{array}{l}1.07 \\
0.50\end{array}$ & $\begin{array}{l}0.60 \\
0.57\end{array}$ & $\begin{array}{l}0.35 \\
0.40\end{array}$ \\
\hline & $0-12$ & $\begin{array}{r}\mathrm{DM} \\
\mathrm{D}\end{array}$ & $\begin{array}{l}3 \\
2\end{array}$ & $\begin{array}{l}1.20 \\
0.30\end{array}$ & $\begin{array}{l}0.72 \\
0.14\end{array}$ & $\begin{array}{l}0.42 \\
0.10\end{array}$ \\
\hline & $0-18$ & $\begin{array}{r}\mathrm{DM} \\
\mathrm{D}\end{array}$ & $\begin{array}{l}2 \\
1\end{array}$ & $\begin{array}{l}1.75 \\
1.00\end{array}$ & $\begin{array}{l}1.06 \\
0.00\end{array}$ & $\begin{array}{l}0.75 \\
0.00\end{array}$ \\
\hline
\end{tabular}

None of the above mean differences between the two treatment series attains statistical significance 
TABLE VII

Decreases in Percentage of Uniformly Stained Bacilli

\begin{tabular}{|c|c|c|c|c|c|c|}
\hline $\begin{array}{l}\text { Type of } \\
\text { disease }\end{array}$ & $\begin{array}{c}\text { Period } \\
\text { (months) }\end{array}$ & $\begin{array}{c}\text { Treatment } \\
\text { series }\end{array}$ & $\begin{array}{c}\text { No. of } \\
\text { Patients }\end{array}$ & $\begin{array}{c}\text { Mean } \\
\text { Decrease }\end{array}$ & $S D$ & $S E m$ \\
\hline \multirow{4}{*}{ LL } & $0-3$ & $\begin{array}{r}\mathrm{DM} \\
\mathrm{D}\end{array}$ & $\begin{array}{l}18 \\
16\end{array}$ & $\begin{array}{l}34.2 \\
37.3\end{array}$ & $\begin{array}{l}19.5 \\
23.0\end{array}$ & $\begin{array}{l}4.6 \\
5.7\end{array}$ \\
\hline & $0-6$ & $\begin{array}{r}\mathrm{DM} \\
\mathrm{D}\end{array}$ & $\begin{array}{l}18 \\
16\end{array}$ & $\begin{array}{l}42.1 \\
45.2\end{array}$ & $\begin{array}{l}23.8 \\
25.5\end{array}$ & $\begin{array}{l}5.6 \\
6.4\end{array}$ \\
\hline & $0-9$ & $\begin{array}{r}\mathrm{DM} \\
\mathrm{D}\end{array}$ & $\begin{array}{l}15 \\
13\end{array}$ & $\begin{array}{l}44.9 \\
48.4\end{array}$ & $\begin{array}{l}24.4 \\
25.9\end{array}$ & $\begin{array}{l}6.3 \\
7.2\end{array}$ \\
\hline & $0-12$ & $\begin{array}{r}\mathrm{DM} \\
\mathrm{D}\end{array}$ & $\begin{array}{l}15 \\
13\end{array}$ & $\begin{array}{l}44.0 \\
48.3\end{array}$ & $\begin{array}{l}24.0 \\
25.1\end{array}$ & $\begin{array}{l}6.2 \\
6.9\end{array}$ \\
\hline \multirow{4}{*}{ BL } & $0-3$ & $\begin{array}{r}\mathrm{DM} \\
\mathrm{D}\end{array}$ & $\begin{array}{l}1 \\
2\end{array}$ & $\begin{array}{l}42.0 \\
30.5\end{array}$ & $\overline{34.6}$ & $\overline{24.5}$ \\
\hline & $0-6$ & $\begin{array}{r}\mathrm{DM} \\
\mathrm{D}\end{array}$ & $\begin{array}{l}1 \\
2\end{array}$ & $\begin{array}{l}55.0 \\
33.5\end{array}$ & $3 \overline{7.5}$ & $2 \overline{6.5}$ \\
\hline & $0 \multimap 9$ & $\begin{array}{r}\mathrm{DM} \\
\mathrm{D}\end{array}$ & $\begin{array}{l}1 \\
1\end{array}$ & $\begin{array}{r}56.0 \\
7.0\end{array}$ & - & - \\
\hline & $0-12$ & $\begin{array}{r}\mathrm{DM} \\
\mathrm{D} \\
\end{array}$ & $\begin{array}{l}1 \\
1 \\
\end{array}$ & $\begin{array}{r}53.0 \\
6.0 \\
\end{array}$ & - & - \\
\hline
\end{tabular}

None of the above mean differences between the two treatment series attains statistical significance

TABLE VIII

Frequency and intensity of Reactions of the two types

\begin{tabular}{|c|c|c|c|c|c|c|c|c|c|c|c|}
\hline \multirow{2}{*}{$\begin{array}{c}\text { Type } \\
\text { of } \\
\text { disease }\end{array}$} & \multirow{3}{*}{$\begin{array}{c}\text { Examination } \\
\text { Pretreatment }\end{array}$} & \multirow{3}{*}{$\begin{array}{c}\begin{array}{c}\text { Treatment } \\
\text { series }\end{array} \\
\text { DM } \\
\text { D }\end{array}$} & \multirow{3}{*}{$\begin{array}{c}\begin{array}{c}\text { No. of } \\
\text { patients }\end{array} \\
20 \\
18\end{array}$} & \multicolumn{8}{|c|}{ Type and intensity of Reaction } \\
\hline & & & & \multirow{2}{*}{$\begin{array}{l}+ \\
1 \\
1\end{array}$} & \multicolumn{3}{|c|}{$\underset{++}{E N L}$} & \multicolumn{3}{|c|}{${\stackrel{+}{ \pm}+{ }_{++}^{L E P R A}}$} & \multirow{2}{*}{$\begin{array}{c}\text { None } \\
9 \\
6\end{array}$} \\
\hline \multirow{4}{*}{ LL } & & & & & $\begin{array}{l}2 \\
0\end{array}$ & $\begin{array}{l}0 \\
0\end{array}$ & $\begin{array}{l}0 \\
0\end{array}$ & $\begin{array}{l}5 \\
7\end{array}$ & $\begin{array}{l}3 \\
4\end{array}$ & $\begin{array}{l}0 \\
0\end{array}$ & \\
\hline & 6 months & $\begin{array}{r}\mathrm{DM} \\
\mathrm{D}\end{array}$ & $\begin{array}{l}20 \\
18\end{array}$ & $\begin{array}{l}3 \\
0\end{array}$ & $\begin{array}{l}1 \\
3\end{array}$ & $\begin{array}{l}2 \\
0\end{array}$ & $\begin{array}{l}0 \\
1\end{array}$ & $\begin{array}{l}3 \\
2\end{array}$ & $\begin{array}{l}1 \\
1\end{array}$ & $\begin{array}{l}0 \\
1\end{array}$ & $\begin{array}{l}10 \\
10\end{array}$ \\
\hline & 12 months & $\begin{array}{r}\mathrm{DM} \\
\mathrm{D}\end{array}$ & $\begin{array}{l}17 \\
15\end{array}$ & $\begin{array}{l}2 \\
4\end{array}$ & $\begin{array}{l}4 \\
3\end{array}$ & $\begin{array}{l}1 \\
1\end{array}$ & $\begin{array}{l}0 \\
3\end{array}$ & $\begin{array}{l}1 \\
1\end{array}$ & $\begin{array}{l}0 \\
1\end{array}$ & $\begin{array}{l}0 \\
0\end{array}$ & $\begin{array}{l}9 \\
2\end{array}$ \\
\hline & 18 months & $\begin{array}{r}\mathrm{DM} \\
\mathrm{D}\end{array}$ & $\begin{array}{l}5 \\
5\end{array}$ & $\begin{array}{l}3 \\
1\end{array}$ & $\begin{array}{l}1 \\
3\end{array}$ & $\begin{array}{l}0 \\
0\end{array}$ & $\begin{array}{l}0 \\
1\end{array}$ & $\begin{array}{l}0 \\
0\end{array}$ & $\begin{array}{l}0 \\
0\end{array}$ & $\begin{array}{l}0 \\
0\end{array}$ & $\begin{array}{l}1 \\
0\end{array}$ \\
\hline \multirow{4}{*}{ BL } & Pretreatment & $\begin{array}{r}\mathrm{DM} \\
\mathrm{D}\end{array}$ & $\begin{array}{l}3 \\
3\end{array}$ & $\begin{array}{l}0 \\
0\end{array}$ & $\begin{array}{l}0 \\
0\end{array}$ & $\begin{array}{l}0 \\
0\end{array}$ & $\begin{array}{l}0 \\
0\end{array}$ & $\begin{array}{l}2 \\
0\end{array}$ & $\begin{array}{l}0 \\
2\end{array}$ & $\begin{array}{l}0 \\
0\end{array}$ & $\begin{array}{l}1 \\
1\end{array}$ \\
\hline & 6 months & $\begin{array}{r}\mathrm{DM} \\
\mathrm{D}\end{array}$ & $\begin{array}{l}3 \\
3\end{array}$ & $\begin{array}{l}0 \\
0\end{array}$ & $\begin{array}{l}0 \\
0\end{array}$ & $\begin{array}{l}0 \\
0\end{array}$ & $\begin{array}{l}0 \\
0\end{array}$ & $\begin{array}{l}0 \\
1\end{array}$ & $\begin{array}{l}0 \\
0\end{array}$ & $\begin{array}{l}0 \\
0\end{array}$ & $\begin{array}{l}3 \\
2\end{array}$ \\
\hline & 12 months & $\begin{array}{r}\mathrm{DM} \\
\mathrm{D}\end{array}$ & $\begin{array}{l}3 \\
2\end{array}$ & $\begin{array}{l}0 \\
0\end{array}$ & $\begin{array}{l}0 \\
0\end{array}$ & $\begin{array}{l}0 \\
0\end{array}$ & $\begin{array}{l}0 \\
0\end{array}$ & $\begin{array}{l}1 \\
0\end{array}$ & $\begin{array}{l}0 \\
0\end{array}$ & $\begin{array}{l}0 \\
1\end{array}$ & $\begin{array}{l}2 \\
1\end{array}$ \\
\hline & 18 months & $\begin{array}{r}\mathrm{DM} \\
\mathrm{D}\end{array}$ & $\begin{array}{l}2 \\
1\end{array}$ & $\begin{array}{l}0 \\
0\end{array}$ & $\begin{array}{l}0 \\
0\end{array}$ & $\begin{array}{l}0 \\
0\end{array}$ & $\begin{array}{l}0 \\
0\end{array}$ & $\begin{array}{l}0 \\
0\end{array}$ & $\begin{array}{l}0 \\
0\end{array}$ & $\begin{array}{l}0 \\
0\end{array}$ & $\begin{array}{l}2 \\
1\end{array}$ \\
\hline
\end{tabular}

The difference between the two treatment series in the proportion of LL patients in reaction (ENL or Lepra) at 12 months is statically significant at the $5 \%$ level. The corresponding difference for ENL reactions only is not significant, even when the intensity of these reactions is taken into account 
TABLE IX

Relative clinical progress of $L L$ and $B L$ patients

\begin{tabular}{l|c|c}
\hline \multirow{2}{*}{$\begin{array}{c}\text { Period } \\
\text { (months) }\end{array}$} & \multicolumn{2}{|c}{$\begin{array}{c}\text { Mean score for } \\
\text { clinical progress }\end{array}$} \\
\cline { 2 - 3 } & $L L$ & $B L$ \\
\hline $0-6$ & 1.26 & 1.83 \\
$0-12^{*}$ & 2.41 & 3.40 \\
\hline
\end{tabular}

* Based on sum of readings for $0-6$ and 6-12 months

The difference between the mean clinical progress of patients with the two types of disease is significant at the $2 \%$ level at $0-6$ months and at the $1 \%$ level at $0-12$ months

\section{TABLE X}

Increases in plasma cholesterol (both types of disease combined)

\begin{tabular}{l|c|c|c|c|c}
\hline $\begin{array}{c}\text { Period } \\
\text { (months) }\end{array}$ & $\begin{array}{c}\text { Treatment } \\
\text { series }\end{array}$ & $\begin{array}{c}\text { Number of } \\
\text { patients }\end{array}$ & $\begin{array}{c}\text { Mean } \\
\text { Increase }\end{array}$ & SD & SEm \\
\cline { 2 - 3 } $0-6$ & DM & 23 & 58.4 & 53.8 & 11.2 \\
& D & 21 & 25.8 & 51.7 & 11.3 \\
\hline $0-12$ & DM & 20 & 69.0 & 58.0 & 13.0 \\
& D & 17 & 13.1 & 65.0 & 15.8 \\
\hline $0-18^{*}$ & DM & 15 & 12.3 & 32.8 & 8.5 \\
& D & 12 & 26.0 & 59.3 & 17.1 \\
\hline
\end{tabular}

$\dagger$ mg. per cent

* The '18-month' readings were made between 15 and 18 months

The mean increase in the DM series was significantly greater than that in the D series at $0-6$ months (at the $5 \%$ level) and at $0-12$ months (at the $1 \%$ level)

\section{References}

Boyd, D. H. A., Stewart, Sheila M., Somner, A. R., Crofton, J. W. and REES, R. J. W. Macrocyclon in the treatment of pulmonary tuberculosis. Tubercle (1959), 40, 369-376.

Cochrane, R. G. : Leprosy in Theory and Practice, pp. 225-228, ed. Cochrane, R. G., Bristol; John Wright \& Sons Ltd. (1959).

Cornforth, J. W., Hart. P. D'arcy, Rees, R. J. W. and Stock, J. A. Antituberculous effect of certain surface-active polyoxythylene ethers in mice. Nature, (Lond.) (1951), 168, 150-153.

Cornforth, J. W., Hart, P. D'arcy, Nicholls, G. A., Rees, R. J. W. and STock, J. A. Antituberculous effects of certain surface-active polyoxyethylene ethers. Brit. J. Pharmacol. (1955), 10, 73-86.

Davison, A. R. and Kools, R. Is erythema nodosum leprosum a favourable occurrence? Int. J. Leprosy (1957), 25, 91-98.

Doull, J. A. Clinical evaluation studies in lepromatous leprosy. First series. Int. J. Leprosy (1954), 22, 377-402.

Doull, J. A., Rodriguez, J. N., Davison, A. R., Tolentino, J. G. and FerNANDEZ, J. V. Clinical evaluation studies in lepromatous leprosy. Second series. Int. J. Leprosy (1957), 25, 173-192.

Doull, J. A., Rodriguez, J. N., Davison, A. R., Tolentino, J. G. and FerNANDEZ, J. V. Clinical evaluation studies in lepromatous leprosy. Third series. Int. J. Leprosy (1958), 26, 219-235. 
Doull, J. A., Rodriguez, J. N., Tolentino, J. G., Fernaniez, J. V., Guinto, R. S., Rivera, J. N. and Mabalay, M. C. Clinical evaluation studies in lepromatous leprosy. Fourth series. Int. J. Leprosy (1961), 29, 291-317.

Hill, A. Bradford: C.I.O.M.S., Controlled Clinical Trials-A Symposium. Blackwell Scientific Publications, Oxford (1960).

Jopling, W. H. Correspondence-Reactional Leprosy. Leprosy Rev. (1959), 30, 194-196.

Lovelock, J. E. and ReEs, R. J. W. Possible site and mode of action of certain lipotropic macromolecules in tuberculosis. Nature, (Lond.) (1955), 175, 161-163.

MaCKANESS, G. B. Artificial cellular immunity against tubercule bacilli. An effect of polyoxyethylene ethers (Triton). Amer. Rev. Tuberc. (1954), 69, 690-704.

McFadzeAN, J. A. Proteinuria in patients with leprosy in Malaya. Tran. roy. Soc. trop. Med. Hyg. (1962), 56, 404-406.

Medical Research Council, Streptomycin in Tuberculosis Trials ComMITTEE. Streptomycin treatment of pulmonary tuberculosis. Brit. med. J. (1948), 2, 769-782.

Muir, E. Editorial: How are we to test for better anti-leprosy drugs? Leprosv Rev. (1955), 26, 137-139.

ReEs, R. J. W. Antituberculous activity of certain non-ionic detergents. Proc. roy. Soc. Med. (1953), 46, 581-583.

REES, R. J. W. The chemotherapeutic activity of Triton WR 1339 and macrocyclon in murine leprosy. Amer. Rev. Tuberc. (1957), 76, 915-916.

Ridley, D. S. Therapeutic trials in leprosy using serial biopsies. Leprosy Rev. (1959), 92, 45-52.

Ridley, D. S. and Jopling, W. H. A classification of leprosy for research purposes. Leprosy Rev. (1962), 33, 119-128.

Solotorovsky, M. and Gregory, F. J. Antituberculous activity in mice of Triton A-20, a nonionic alkyl-aryl polyether alcohol, used alone and in combination with dihydrostrepomycin. Amer. Rev. Tuberc. (1962), 65, 718-721.

WADE, H. W. Editorial-Continuities. Internat. J. Leprosy (1961), 29, 360-361.

Waters, M. F. R. and ReEs, R. J. W. Changes in the morphology of Mycobacterium leprae in patients under treatment. Int. J. Leprosy (1962), 30, 266277. 